VOL. 8, NO. $1(2020) 64-71$

\title{
JURNAL NATAPRAJA:
}

Kajian Ilmu Administrasi Negara

2406-9515 (p) / 2528-441X (e) https://journal.uny.ac.id/index.php/natapraja

\section{Model of Procedures Cash Disbursement System For Purchasing Assets in Village Accounting Systems}

Khozin Arief ${ }^{1}$

Politeknik Negeri Bandung, Indonesia

\section{ARTICLE INFO}

Article history:

Received 3 April 2019

Received in revised form 7

October 2019

Accepted 10 December 2019

\section{ABSTRACT}

This study aims to create a procedure model of cash expenditure system assets in the village accounting system to be used in villages throughout Indonesia so that the administration of village accounting can be run accountable, transparent, can be accounted for according to applicable laws. Based on the preliminary interview conducted by the researcher to the village officials, it was found that in the implementation of the procedure for issuing cash on asset purchases, procedural errors sometimes occurred in the village accounting administration due to the incomplete documentation of the procedure model. This procedural error led to irregularities in village financial managers. Therefore we need a well-documented and complete procedure for cash disbursement procedures for asset purchasing as a guideline for administering village accounting. The methodology of this research was carried out by data collection techniques through interviews, observation, and system documentation carried out in the villages of Parongpong District, West Bandung Regency, West Java Province, with stages starting from planning, surveying, analyzing and designing systems. In designing this village accounting procedure model, the author follows applicable government laws and regulations and literature studies on village accounting.

Keyword:

System, Accounting, Village

\section{INTRODUCTION}

According to Law No. 6 of 2014 concerning Villages, each village would get a fund of Rp. 1.400.000.000 / year, and each village must be held accountable for its use and reporting in an accountable and transparent manner. However, the facts in the field are that there are village accounting 
administrators who have the wrong procedures in administering village finances, especially in the village accounting administration procedures for cash disbursement of asset purchases. The procedural error in administering an asset purchase cash disbursement is caused by two things: the first thing, lack of knowledge about the procedure. The second thing, the procedure for issuing cash on asset purchases have not yet been documented as their guidance in carrying out administration in accordance with government laws and regulations (Permen No. 113 Tahun 2014 Tentang Pengelolaan Keuangan Desa; Permendagri No. 32 Tahun 2006 Tentang Pedoman Administrasi Desa).

Therefore, to administer the village accounting for cash disbursement of asset purchases can runs accountable, transparent, can be accounted for, and in accordance with applicable law, then we need a system model administration procedure for cash disbursement of asset purchases. With the existence of this system of procedures will reduce the mistakes of village administration staff that still lack in terms of village accounting administration. Therefore detailed village accounting systems and procedures are required on the cash disbursement of asset purchases for use in villages in Indonesia as guidelines for village accounting administration. In addition, the existing administration system and procedure are only guided by the law, and there are no documented complete system procedures manual.

The purpose, benefits, and outcomes of this study are to produce a documented system of cash disbursement of asset purchases and can be used as a guideline to assist village officials in administering cash disbursement of asset purchases in accordance with applicable laws and government regulations. This study also has benefits and research outcomes in the form of a documented procedure system model to be used in the community service of lecturers in the villages and for student practicum activities in the Government Accounting course.

The accounting system is a human-made system. This system consists of computer components and integrated manual components that have a unified whole for collecting, inputting, storing, and managing data with the aim of producing accounting information for users of accounting information (Gelinas, Sutton, and Hunton, 2016; Romney, Marshall B., Stembart, Paul John, 2017). Another understanding of accounting information systems is the organization of forms, documents, records, and reports that are coordinated in such a way as to provide financial and accounting information needed by management to facilitate organizational management (Mulyadi, 2014; Narko, 2004). Accounting system design is the steps taken to design a system that does not yet exist or modify an existing accounting system in an organization (Gelinas, Sutton and Hunton, 2016). The village accounting system is the recording and input of the village transaction process consisting of documents, forms, and then record and input are carried out to produce financial and accounting report information used by parties related to the village (Sujarweni, Wiratna, 2015).

\section{METHOD}

The research method in this study uses qualitative methods. In this study, researchers sought sources of data in the form of primary data derived from interviews, observations, and documentation as well as secondary data derived from laws on villages, government 
regulations on villages, and literature studies from books on villages.

Data Collection Techniques consist of (1) Observation. In this case, the researcher made observations with a passive participation technique, that is, the researcher came to the research object, namely the village employee who was administering village accounting in the area of asset purchasing but did not participate in the activities of the activity (Sugiono, 2012). (2) Interview, in this case, the researchers conducted interviews with the semi-structural technique. This technique is used by researchers so that informants are more open in providing information to researchers in the form of data about asset purchasing on Village Accounting assets (Sugiono, 2012). (3) Documentation, In this case, the researcher carries out the system documentation and procedures by collecting data in the form of a system of procedures for asset purchasing carried out through interviews, collecting forms, records of financial data then the researcher will document in the form of flowcharts (Sugiono, 2012).

The focus of this research is in the villages of Parongpong District, West Bandung Regency, and West Java Province. The investigators consisted of the village head, village secretary, village treasurer, asset purchase officer, and financial and accounting manager. Activities investigated are all activities of village officials relating to the cash disbursement of asset purchases consisting of systems and procedures, documents, and form forms (Sugiono, 2012).

\section{RESULT AND DISCUSSIONS:}

After conducting research, it was found that village officials had difficulty translating the accounting system procedures for the purchasing of assets from the law into the procedures used. For example, how to purchase asset procedures such as computer purchases. Therefore, we need a model of the procedure for the cash disbursement of asset purchases, as the researchers designed.

The model of the procedure that the researcher designed was abstract, so the researcher described it in the form of a system narrative and flowchart. Flowchart documentation displays a picture both logically and physically of who, what, and how the system works, including describing the operating system and information systems and data processing activities both manually and by using a computer.

In a flowchart that has been designed, consists of column items. These items consist of a description column, an entity column (i.e., village treasurer, the village head, village secretary, asset purchasing officer, and village accounting officer). This flowchart also describes the documents used, such as SPP (Payment Request Letter), SPB (Bank Withdrawal Slip), SPP Registration Book, and a description of the flow of procedures.

System design and procedures for cash disbursement of asset purchases in narrative form

System and Procedure Design in the form of narrative is a description of the accounting system procedures that exist in the village in written form (words) in detail and clearly. This design aims as a guide for village officials in carrying out village financial administration procedures in terms of asset purchase. The narrative system that the author designed at Figures 1 and 2 .

The treasurer makes the SPP (Letter of Payment Request) for the purchase of assets by filling in the date and number and other fields. After completion, the SPP is given to 
Figure 1. Flowchart Procedures for Cash Disbursement of Asset Purchases

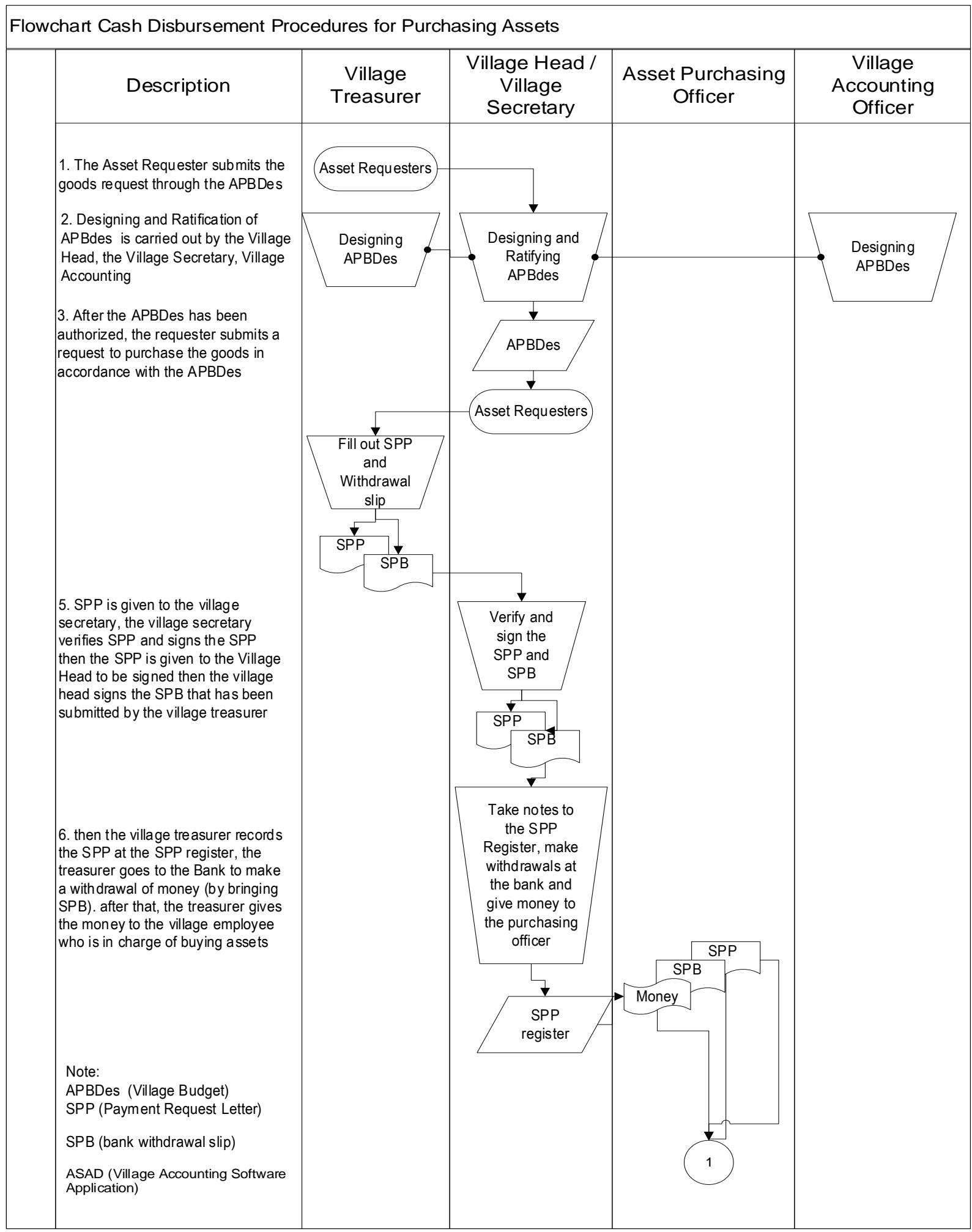

the village secretary to be verified and signed. After that, the SPP is given to the Village Head to be signed. In addition to signing the SPP, the village head also signs the SPB (Bank Withdrawal Slip) that has been submitted by the village treasurer (the 
Figure 2. Flowchart Procedures for Cash Disbursement of Asset Purchases (continued)

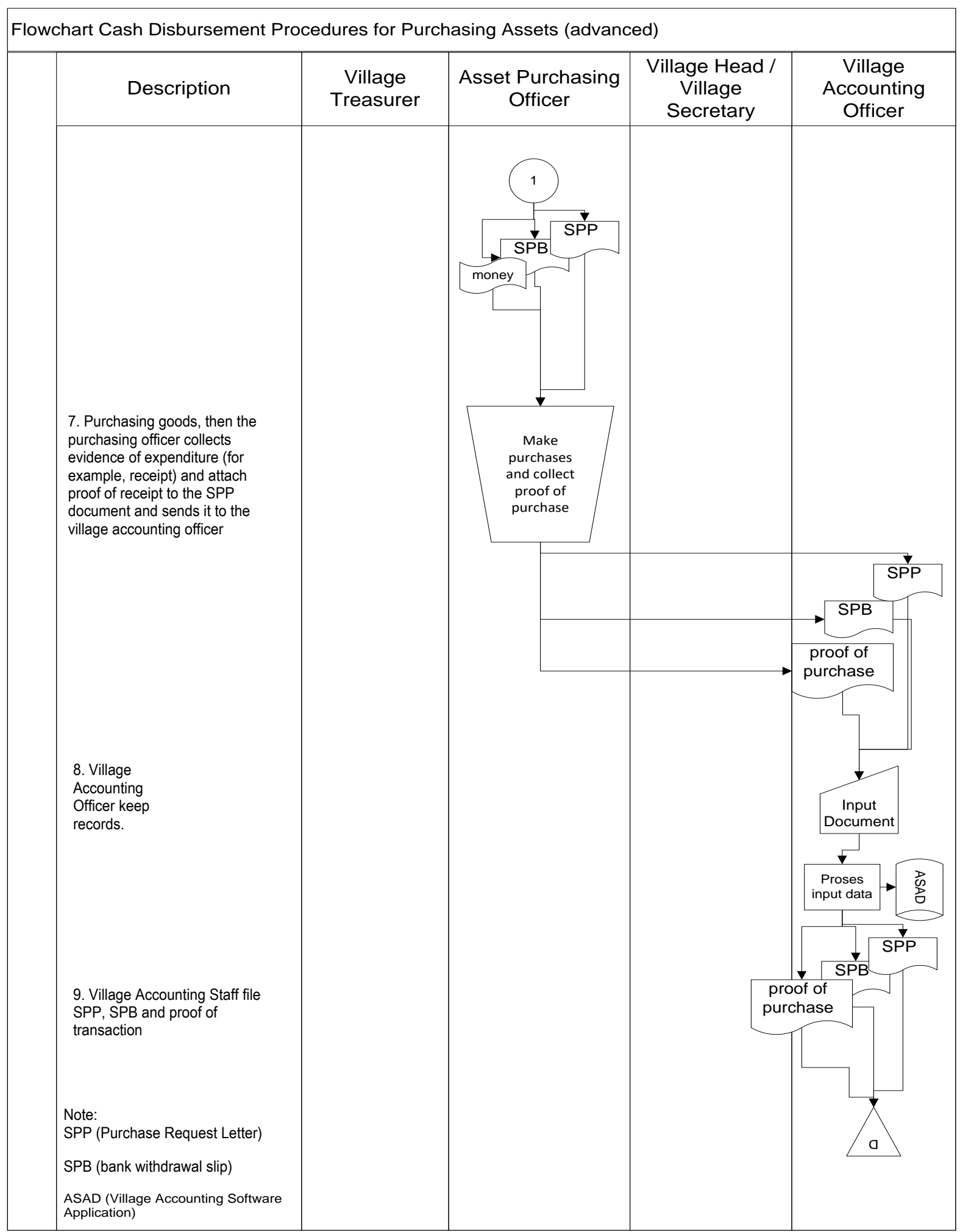

withdrawal slip is already available in the village because it is already in cooperation with the bank).
After that, the village treasurer records the SPP in the SPP register and goes to the Bank to make a withdrawal (with a bank 
withdrawal slip). After that, the treasurer gives money to the asset purchase officer. After the officer has finished buying assets, the officer collects proofs of purchase (e.g., purchase invoices, proof of purchase, etc.) and is given to the treasurer. After that, the treasurer attaches evidence of the purchase transaction to the SPP document. After that, the village accounting officer inputs to the Village Accounting Software.

System design and procedure for cash disbursement of asset purchases in the form of a flowchart

Figures 1 and 2 are the draft flowchart of the procedure for cash disbursement of asset purchases. This procedure begins with the product requester submitting the request for goods through a meeting to discuss the RAPBDes (Village Income and Expenditure Budget Plan). This meeting discusses the village income and expenditure budget plan, including the asset needs a budget and then is ratified by the village head to become the APBDes (Village Income and Expenditure Budget). After the APBDes is passed, the next step is the purchase of assets. In purchasing assets, the Village Treasurer fills in the SPP (Letter of Purchase Request) document.

This SPP form consists of the head form that explains the name of the village, subdistrict, and district. The SPP document is a form that consists of the contents. SPP Form filling consists of SPP Number, APBDes Number, The Amount of Payment Requested, The Purposes of Purchasing Asset, Treasurer Name, Treasurer Address, Bank Account Number, Bank Name, Chart of Accounts, Village Treasury Signature, Village Secretary Signature, and Village Head Signature.

After that, the village treasurer fills in the SPB (bank withdrawal slip). This slip is provided by the bank because usually, a village has cooperated with the bank. So, the bank gives a withdrawal slip that hasn't been filled to the village. This SPB document consists of the following entry points: date of withdrawal, name of the account holder, account number, amount of money to be withdrawn in number and letter, withdrawal statement, stoned signature, the signature of withdrawal.

Furthermore, the SPP document is entered into the SPP register of an SPP register book that has been issued, and this book consists of the following columns: column serial number, date issued SPP, No. SPP, for what needs, bank account number, and bank name. After the village secretary withdraws money from the bank, then the money is given to the asset purchase officer, and then this officer will make the asset purchase. After that, the purchasing officer collects evidence of the purchase transaction and is given to the village accounting clerk to input into the Village Accounting Software Application, and then documents in the form of SPP, BPB, and other evidence are archived by date

\section{CONCLUSION}

The conclusion of this study, the village requires documented administration procedures as a reference tool in conducting village accounting administration in the field of asset purchase. This was seen during the preliminary survey where the findings in the field of village accounting administration staff had difficulties in studying the laws and government regulations in conducting village accounting administration in the field of asset purchase. It is because of their limited competence in accounting and administration. With the model of the village accounting system procedure for purchasing assets, village employees can follow the correct procedures in accordance with government laws and regulations so that 
they become a reference for village employees in managing village finances in asset purchases and avoiding wrong procedures.

The suggestion for villages in Indonesia is to use the results of this study. The results of this study are a model of accounting procedures for asset purchases in the form of flowcharts and system narratives. The results of this study were based on government laws and regulations. If villages in Indonesia use the results of this study, it is hoped that village officials will not carry out any wrong procedures in administering village accounting in the area of asset purchases.

\section{REFERENCE}

Agung Pratama, M. (2015). Analisis Efektivitas Corporate Social Responsibility Dalam Program Kemitraan Badan Usaha Milik Negara (Studi Kasus pada Perkembangan UMKM Mitra Binaan PT. Perkebunan Nusantara VII Unit Usaha Rejosari). NATAPRAJA. https://doi.org/10.21831/jnp.v1i1.344 4

Bastian, I. (2007). Sistem Informasi Sektor Publik. Jakarta: Salemba Empat.

Gelinas, Sutton, and Hunton. (2016). Accounting Information System. USA: South-Western.

Gelinas, Sutton, and Hunton. (2016). Acquiring, Developing, and Implementing Accounting Information System. USA: South-Western.

George H. Bondar, Wiliam S. Hopwood. (1995.). Sistem Informasi Akuntansi. Jakarta: Salemba Empat.

Hall, J. A. (2002). Sistem Informasi Akuntansi. Jakarta: Salemba Empat.
Hamzah, A. (2005). Tata Kelola Desa Menuju Desa Mandiri, dan Partisipatoris. Jawa Timur,: Pustaka Jawa Timur.

Krismiaji. (2005). Sistem Informasi Akuntansi. Yogyakarta: UPP AMP YKPN.

Miftah, A. Z., Sugandi, Y. S., \& Sukarno, D. (2019). Importance Performance Analysis Kualitas Pelayanan Badan Pengelolaan Pendapatan Daerah Kota Bandung. NATAPRAJA.https://doi.org/ 10.21831 /jnp.v7i1.2316

Mulyadi. (2014). Sistem Akuntansi. Jakarta: Salemba Empat.

Narko. (2004). Sistem Akuntansi. Yogyakarta: Yayasan Pustaka Nusatama.

Nourmanita, N. A. (2015). Belanja Publik (Expenditure Assignment) Antara Masalah Dan Efektivitas Anggaran Belanja. NATAPRAJA. https://doi.org/ 10.21831/jnp.v4i1.126 13

Nurtanzila, L. (2016). Kemandirian Fiskal Daerah Otonomi: Kesiapan Daerah Dalam Pelimpahan Kewenangan Pengelolaan Pajak Bumi Dan Bangunan Perkotaan Dan Perdesaan. NATAPRAJA. https://doi.org/10.21831/jnp.v4i1.12 611

Permen No. 113 Tahun 2014 Tentang Pengelolaan Keuangan Desa. (n.d.).

Permendagri No. 32 Tahun 2006 Tentang Pedoman Administrasi Desa. (n.d.).

Romney, Marshall B., Stembart, Paul John. (2017). Accounting Information System. New Jersey: Prentice Hall.

Sugiono. (2012). Metode Penelitian Kuantitatif Kualitatif dan R\&D. Bandung: Alfabeta.

Sujarweni, Wiratna. (2015). Akuntansi Desa. Yogyakarta: Pustaka Baru Press. 
UU RI NO. 6 Tahun 2014 Tentang Desa.

(n.d.). 